\title{
MEMBANGUN MOTIVASI BERAGAMA MELALUI PENGUATAN MAKNA HIDUP BAGI PEREMPUAN PEKERJA SEKS KOMERSIAL DI KOMPLEKS LOKALISASI LORONG INDAH KABUPATEN PATI JAWA TENGAH
}

Fatma Laili Khoirun Nida

fatmalaili@stainkudus.ac.id

\begin{abstract}
The will to live meaningfully is a fundamental need for all humans. The fulfillment of the meaningful aspects of life will contribute to its spiritual quality, including in the dynamics of religious life. In this study, it will be proven that the achievement of the meaning of life will contribute to increasing individual religious motivation, including groups of individuals who are far from religious and moral values such as female commercial sex workers. The subjects in this study were female commercial sex workers in the Lorong Indah Kabupaten Localization Complex in Pati, Central Java. By using observation, questionnaire and interview methods as a form of a qualitative approach, the researcher proves that the concept of religious motivation as a basic need and the nature of every human being is also a subject's need. Religious motivation shows better conditions when they are also able to achieve the fulfillment of the meaningfulness of life. The process of achieving the meaning of life can act as medium to develop religious motivation.
\end{abstract}

Keywords: Meaning of Life, Religious Motivation, Women Commercial Sex Workers.

Abstrak: Kehendak untuk hidup bermakna merupakan kebutuhan yang bersifat fundamental bagi seluruh manusia. Terpenuhinya aspek kebermaknaan hidup akan memberi kontribusi bagi kualitas spiritualnya termasuk dalam dinamika kehidupan beragama. Dalam penelitian ini akan membuktikan bahwa pencapaian makna hidup akan memberi kontribusi pada peningkatan motivasi beragama individu, termasuk pada kelompok individu yang jauh dari nilai-nilai agama dan moralitas seperti perempuan pekerja seks komersial. Subjek dalam penelitian ini adalah perempuan pekerja seks komersial di Kompleks Lokalisasi Lorong Indah Kabupaten Pati Jawa Tengah. Dengan menggunakan metode observasi, angket dan interview sebagai bentuk dari pendekatan kualitatif, peneliti membuktikan bahwa konsep motivasi beragama sebagai kebutuhan dasar dan menjadi fitrah setiap manusia juga menjadi kebutuhan subjek. Motivasi beragama menunjukan kondisi lebih baik ketika mereka juga mampu mencapai pemenuhan terhadap kebermaknaan hidup. Proses pencapaian makna hidup ternyata dapat berperan sebagai media untuk mengembangkan motivasi beragama.

Keywords: Makna Hidup, Motivasi Beragama, Perempuan Pekerja Seks Komersial.

\section{Pendahuluan}

Dewasa ini, wacana penutupan lokalisasi terus bergulir seiring dengan realisasi kebijakan penataan perkotaan oleh pemerintah di be- berapa daerah. Fenomena penutupan beberapa lokalisasi tidak serta merta mengakhiri rumitnya permasalahan social seputar bisnis prostitusi. Beragam permasalahan yang lebih rumit 
muncul mengiringi realisasi kebijakan tersebut. Kondisi tersebut menjadi gambaran bahwa fenomena bisnis prostitusi merupakan warna kehidupan yang menyimpan segudang masalah baik bagi pelaku bisnis yang terlibat di dalamnya maupun bagi masyarakat secara luas yang secara langsung atau tidak mereka terkena imbas dari keberadaan bisnis tertua dalam sejarah dunia tersebut.

Membahas seputar kehidupan prostitusi tentunya tidak akan terlepas dari keberadaan pekerja seks komersial yang terlibat di dalamnya. Pekerja seks komersial (PSK), atau lebih akrab disapa pelacur, lonthe, WTS, atau istilah lainnya merupakan kelompok masyarakat yang paling tidak beruntung dari pertukaran seksual kontraktual antara pelacur dan pelanggannya. Dengan hanya menerima upah sekitar $30 \%$ dari jasa pekerjaannya itu maka sangat wajar bila mereka menjadi golongan yang terpinggirkan diantara pekerjaan jasa pelayanan seksual yang telah mentradisi. ${ }^{1}$ Keberadaan perempuan pekerja seks komersial dimanapun berada selalu diidentikkan dengan perempuan jalang, amoral, tidak tahu malu, penggoda lelaki, sumber penyakit HIV, dan beragam pandangan stereotype negative lainnya sebagai label yang melekat dari konsekwensi pekerjaan yang dilakoninya.

Terlepas dari label buruk yang disandang oleh kelompok perempuan pekerja seks komersial tersebut, bagaimanapun juga mereka sejatinya adalah manusia yang sama dengan kelompok sosial yang lain. Sebagai manusia biasa, mereka memiliki kebutuhan dasar yang tidak dapat mereka lepas sekalipun dalam posisi mereka sebagai PSK kebutuhan tersebut terabaikan, yakni kebutuhan untuk hidup bermakna. Eksistensi kebutuhan untuk hidup bermakna untuk saat ini terabaikan karena kuatnya kebutuhan yang lebih mendasar yakni kebutuhan primer. Itu sebabnya mereka tidak memiliki pilihan lain selain untuk tetap bertahan pada dunia prostitusi.
Rentetan permasalahan hidup yang dimiliki para perempuan pekerja seks komersial juga sama dengan kehidupan masyarakat umumnya, bahkan adakalanya lebih rumit. Himpitan ekonomi dan permasalahan yang mereka hadapi kadangkala menjadi factor pemicu mereka memilih pelacur sebagai profesi pilihannya. Dalam rumitnya permasalahan yang mereka hadapi, mereka tetap memiliki kebutuhan untuk mencapai hidup yang bermakna. Sama halnya dengan individu yang lain. Tentu bukanlah hal mudah bagi perempuan pekerja seks komersial untuk mencapai kebermakanaan hidup mereka. Jauhnya mereka dengan nilai-nilai yang bersifat normatif dan religious akan menjadi salah satu factor yang mempersulit mereka dalam proses pencapaian makna hidup.

Kehendak untuk hidup bermakna merupakan kebutuhan yang bersifat fundamental bagi seluruh manusia. Motivasi yang sangat kuat dalam diri manusia untuk memperoleh hidup yang bermakna berlaku pada seluruh manusia tanpa mengenal lapisan budaya maupun aspek-aspek kemanusiaan yang lain. Mutlaknya kebutuhan akan makna hidup ini ditunjukkan oleh beberapa penelitian tentang kebutuhan individu akan makna hidupnya. Hasil pengumpulan pendapat umum di Prancis, misalnya, menunjukkan 89\% responden percaya bahwa manusia membutuhkan "sesuatu" demi hidupnya, sedangkan $61 \%$ di antaranya merasa bahwa ada sesuatu yang untuknya mereka rela mati. ${ }^{2}$ Bahkan dalam sebuah penelitian menyebutkan bahwa dua diantara sepuluh penyebab kematian tertinggi di Dunia Barat adalah alkoholisme dan bunuh diri yang disebabkan oleh krisis makna hidup yang menimpa mereka . ${ }^{3}$

Beberapa bukti empiris tersebut di atas mampu menggambarkan bahwa eksistensi kebermaknaan hidup menjadi kebutuhan yang mutlak khususnya pada masyarakat yang telah mengalami kompleksitas permasalahan hidup 
Fatma Laili Khoirun Nida | Membangun Motivasi Beragama 109

yang berindikasi adanya stressor yang kerap berdampak pada ketidakstabilan emosi, melemahnya kepercayaan diri, hilangnya motivasi untuk berkarya, merosotnya nilai-nilai kehidupan dan dorongan untuk berperilaku amoral yang mengarah pada psikososial. Kondisi ini kerap dialami oleh mereka para perempuan pekerja seks komersial mengingat sulitnya mereka untuk mencapai kebermaknaan dalam hidupnya sebagai akibat kehidupan prostitusi yang memposisikan mereka dalam kelompok marginal.

Membicarakan tentang dunia prostitusi di Indonesia, keberadaan kompleks lokalisasi Lorong Indah cukup mewarnai dinamika kehidupan prostitusi di wilayah Pantura bagian tengah. Eksistensi kompleks lokalisasi ini ikut berkontribusi dalam menjadikan jalur pantura sebagai jalur prostitusi di wilayah Jawa. Jumlah pekerja seks komersial di lokalisasi ini cukup besar yakni sekitar 200 PSK aktif dengan kisaran usia 17- 40 tahun yang menghuni sekitar 45 rumah bordil. Fenomena menarik yang ditangkap oleh peneliti dalam satu kesempatan observasi adalah animo para PSK yang cukup tinggi dalam kegiatan keagamaan yang rutin diadakan dua minggu sekali tepatnya di hari senin minggu pertama dan kedua. Bagi peneliti, keikutsertaan mereka dalam menghadiri pengajian rutin tersebut merupakan gambaran bahwa masih terdapat kehidupan religious dibalik kehidupan gelap mereka sebagai perempuan yang identik sebagai pemuas nafsu. Sementara bila ditinjau dari konsep kebermaknaan hidup, Crumbaugh ${ }^{4}$ menjelaskan bahwa salah satu upaya untuk memenuhi kebutuhan untuk mencapai hidup bermakna, peran agama ikut berkontribusi di dalamnya.

Penelitian ini bersifat kualitatif, dimana pe-

${ }^{1}$ Nur Syam, Agama Pelacur : dramaturgi Transendental, Yogyakarta: LKiS, 2010,hal 56

${ }^{2}$ Frankl, Logoterapi ; Terapi Psikologi Melalui Pemaknaan Eksistensi, terj, Yogyakarta: Kreasi Wacana, 2003, hal 110

${ }^{3}$ Danah Zohar dan Ian Marshall, SQ; Memanfaatkan Kecerdasan Spiritual dalam Berfikir Holistik Untuk Memaknai Kehidupan, terj, Bandung: Mizan Media Utama, 2001, hal 18 neliti berusaha mengungkap lebih jauh tentang upaya membangun motivasi beragama PSK di kompleks lokalisasi Lorong Indah Kabupaten Pati melalui penguatan makna hidup mereka. Metode pengumpulan data menggunakan teknik observasi, angket dan wawancara yang dilakukan peneliti dalam kurun waktu 3 bulan. Keterlibatan peneliti dalam keseharian PSK khususnya dalam momen-momen khusus seperti acara pengajian, kursus menjahit, berkebun dan beberapa kegiatan konseling membantu peneliti untuk menemukan kondisi kebermaknaan hidup dan motivasi beragama subjek secara lebih utuh sebagai variabel dalam penelitian ini.

\section{Pembahasan}

\section{Motivasi Beragama}

Allah telah menciptakan manusia sebagai makhluk yang memiliki kesempurnaan secara pripurna disbanding makhluk ciptaan Allah lainnya. Hanya manusialah yang diibekali oleh akal pikiran dan hawa nafsu secara sekaligus, manusia juga diberikan amanat oleh Allah SWT untuk menjadi pemimpin dan perawat bumi tempat tinggal manusia. Sebagai konsekwensi dari kesempurnaan penciptaannya, manusia juga dilahirkan dalam keadaan fitrah dan memiliki insting untuk beragama, namun dikemudian orang tuanyalah yang menjadikan manusia tersebut majusi, nasrani atau pun islam, hal ini juga sesuai dengan hadits yang nabi sampaikan. Karena telah dibuktikan bahwa manusia memang dalam dunia ini dan kehidupan sehari-hari memang membutuhkan agama dan membutuhkn tempat bersandar, dalam hal ini ialah tuhan.

Motivasi berasal dari bahasa Inggris motivation yang kata kerjanya adalah motivate yang berarti " to provide with motives, as the characters in a story or play" yang artinya "sebagai karakter dalam cerita atau permainan". Motivasi adalah

${ }^{4}$ Hanna Djumhana Bastaman, Integrasi Psikologi Dengan Islam, Menuju Psikologi Islam, 1995, Yogyakarta, pustaka pelajar, 1995: hal. 198 
dorongan yang menyebabkan seseorang melakukan suatu perbuatan. Dalam istilah psikologi motivasi adalah istilah umum yang merujuk kepada pemenuhan kebutuhan dan tujuan tingkah laku. Dorongan itu dapat muncul dari tujuan dan kebutuhan. Berdasarkan munculnya, maka motivasi dapat muncul dari dalam diri seseorang yang disebut motivasi intrinsic yang bersifat batin, juga bisa berasal dari luar diri yang disebut motivasi ekstrinsik. Motivasi yang bersifat batin atau intrinsic dapat dilihat dari beberapa contoh seperti dorongan untuk memperoleh pujian, penghormatan, kepuasan, kenikmatan dan lainnya, sedangkan motivasi ekstrinsik adalah motivasi yang bersifat fisik atau materi seperti keinginan untuk mendapat hadiah berupa materi.

Berdarkan uraian di atas, dapat dikatakan bahwa munculnya dorongan untuk berperilaku disebabkan banyak hal. Bagi motivasi intrinsic, pemicunya dapat disebabkan oleh kebutuhan, pengetahuan, dan aspirasi cita-cita. Sedangkan motivasi ekstrinsik muncul sebagai akibat dari tiga hal pula yakni ganjaran, hukuman, persaingan atau kompetisi. Sejalan dengan itu maka motivasi berguna dan bermanfaat untuk menggerakkan tingkah laku, mengarahkan tingkah laku, menjaga dan menopang tingkah laku. Selain itu motivasi memiliki peranan yakni : 1) menolong manusia untuk berbuat sesuatu; 2) menentukan arah perbuatan manusia; 3 ) menyeleksi perbua$\tan$ manusia. ${ }^{5}$

Terdapat suatu hubungan antara motivasi, kebutuhan, dan pemuasan. Motivasi dan kebutuhan adalah dua kata yang saling terkait satu dengan lainnya. terkadang motivasi digunakan sebagai kata yang bermakna kebutuhan dan juga sebaliknya. Kebutuhan dapat memicu suatu motivasi dan motivasi mendorong seseorang untuk memenuhi kebutuhan melalui pemuasannya. Disaat kadar darah dalam tubuh seseorang berkurang, maka sudah menjadi kebutuhan dalam dirinya untuk memenuhinya. Dari sinilah timbul motivasi lapar yang merupakan implikasi dari berkurangnya kadar darah dan makanlah yang menjadi pemuasnya. Aktifitas yang timbul dari suatu motivasi adalah aktivitas pencarian (dalam hal ini makanan) dan aktivitas konsumsi (atau memakan makanan). Dengan demikian, motivasi bukanlah sesuatu yang secara fisik terlihat. namun, ia adalah satu rasa internal yang mengarahkan perilaku internal dalam diri individu manusia. ${ }^{6}$

Walgito menjelaskan bahwa motivasi adalah keadaan dalam diri individu yang mendorong perilaku kearah tujuan. Selanjutnya, terdapat tiga aspek dalam motivasi yakni:keadaan yang terdorong dalam diri organism, perilaku yang timbul dan terarah karena keadaan tersebut serta tujuan yang akan dicapai oleh pelaku. ${ }^{7}$

\section{A. Macam-Macam Motivasi}

Motivasi terbagi menjadi dua, yaitu:

\section{Motivasi Naluriah}

Motivasi naluriah adalah motivasi yang muncul dari suatu kekurangan atau ketidakseimbangan fisiologis. Hal ini disertai dengan kekhawatiran dalam diri hingga mampu menggerakkan semua daya dalam diri untuk menutupi kekurangan tersebut dan menghilangkan kekhawatiran yang timbul dengan aktivitas-aktivitas yang bertujuan untuk pemuasannya. Contoh motifmotif naluriah (motivasi menjaga kelangsungan hidup), yaitu : ${ }^{8}$ motif lapar, motif haus, motif sekresi, motif tidur dan istirahat, motif bernafas, motif menjaga keturunan yang dibagi menjadi dua yaitu motif seksual dan motif keibuan.

\section{Motif Kognitif}

Motif kognitif ini tidak berkaitan dengan dasar-dasar biologis dalam diri manusia. Ia ada-

${ }^{5}$ Baharuddin, Paradigma Psikologi Islam; Studi tentang Elemen Psikologi dari Al qur'an, Yogyakarta, Pustaka Pelajar,hal 234

${ }^{6}$ Muhammad Izuddin Taufiq, Panduan Lengkap dan Praktis Psikologi Islam, Gema Insani, Jakarta, 2006, Hlm. 655-656.

${ }^{7}$ Bimo Walgito, Psikologi Umum, Yogyakarta, Andi, 2003. Hal 169 
lah kebutuhan yang dipelajari manusia dari lingkungan dan sosial masyarakatnya. Tujuan dari motif kognitif adalah untuk menjaga diri dan mengembangkan kemampuannya. Dengan memenuhi dan memuaskannya, maka terealisasilah keseimbangan kejiwaan. Berlawan arah dengan keseimbangan fisik dan metabolisme tubuh yang terealisasi bila manusia mampu memnuhi kebutuhan atau motif naluriah instingtifnya. ${ }^{9}$

\section{Contoh-contoh motif kognitif, yaitu:}

a. Motif Psikis

\section{1) Motif keamanan}

Rasa aman bagi seorang muslim tidak hanya dibutuhkan dalam kehidupan dunia saja, namun ia pun membutuhkannya kelak pada hari kiamat dari siksa Allah. Dengan persepsi inilah perilaku seorang muslim diarahkan untuk selalu beriman kepada Allah dan hari kiamat, dan pemenuhannya diarahkan pada penegakan nilainilai yang ada pada ajaran agamanya. ${ }^{10}$

\section{2) Motif untuk mengetahui sesuatu}

Allah telah menganugerahkan akal pikiran bagi manusia, yang memberikan makna lebih dari segala hal yang ditangkap oleh daya indrawinya. Dengan akal pikiranlah manusia mampu memahami segala segala hal dengan baik dan kemudian mengajarkan apa yang didapatnya kepada generasi penerusnya. Motif inilah sebenarnya yang menggerakkan manusia untuk memajukan ilmu pengetahuan dan membangun peradabannya. Selain itu juga, Allah telah memberikan wahyu kepada manusia, suatu ilmu pengetahuan yang melebihi penalaran akal manusia. Dengan wahyu lah manusia mampu memenuhi rasa ingin tahunya akan hal-hal ghaib dan hal-hal yang tidak bisa dilihatnya. ${ }^{11}$

\section{3) Motif untuk mengaktualisasikan dirinya}

Islam telah mengukuhkan motif ini bila individu mampu memenuhinya dengan batasan yang telah ditetapkan. Islam pun telah menjadikan pertumbuhan pertumbuhan motif ini sebagai salah satu tujuan pendidikan Islam. Salah satu tujuan pendidikan islam adalah dengan memendekkan masa tumbuh kembang pola pikir anak sesingkat mungkin dan mempercepat anak untuk bisa belajar bertanggungjawab.

Islam membangun konsep ini dengan landasan prasangka terbaik pada tiap individu manusia. Rasa percaya diri seseorang untuk bisa mengemban tanggung jawab akan tetap tampak walaupun dalam kondisi rentan sekalipun, yakni dalam masalah keimanan. Seorang individu mampu memutuskan pilihannya dengan segala kebebasannya, tanpa dipaksa atau diintimidasi. $^{12}$

\section{b. Motif Sosial}

\section{1) Motif cinta}

Cinta adalah satu emosi. Motif untuk dicintai adalah salah satu kebutuhan manusia dari manusia lainnya. Cinta dari sesamalah yang menimbulkan satu motivasi sosial dan mengarahkannya untuk bisa berperilaku pra-sosial kepada sesamanya. Seorang muslim hendaknya selalu memprioritaskan cinta Allah, Rasul-Nya, dan kaum mukminin. Hendaknya ia mampu menjadikan cintanya kepada Allah dan Rasul-Nya sebagai satu landasan kuat untuk bisa mencintai sesamanya dengan tulus. ${ }^{13}$

\section{2) Motif penghargaan}

Dalam perspektif Islam, setiap individu hendaknya melakukan segala sesuatunya dengan tujuan utamanya yakni mengharapkan keridhaan Allah. Allah berfirman, "Dan katakanlah, "Bekerjalah kamu, maka Allah dan Rasul-Nya serta
${ }^{8}$ Ibid, Hlm. 658-659.

${ }^{9} \mathrm{Ibid}, \mathrm{Hlm} .680$.

${ }^{10} \mathrm{Ibid}, \mathrm{Hlm} .683$.

${ }^{11}$ Ibid, Hlm. 684

${ }^{12} \mathrm{Ibid}, \mathrm{H}$ lm. 685.

${ }^{13} \mathrm{Ibid}, \mathrm{Hlm} .686$. 
112 NUANSA Vol. XII, No. 1, Juni 2019

orang-orang mukmin akan melihat pekerjaanmu itu, dan kamu, dan kamu akan dikembalikan kepada (Allah) Yang Mengetahui hal yang ghaib dan yang nyata, lalu diberikan-Nya kepada kamu apa yang telah kamu kerjakan". (at-Taubah 105)

Pemahaman ayat di atas tidak bertentangan dengan kebutuhannya untuk bisa dihargai oleh sesamanya. Bedanya hanya terletak pada kualitasnya saja. Orang kafir hanya memedulikan pandangan manusia saja hingga ia akan melakukan segala sesuatunya yang menurut pandangan manusia adalah baik. Sedangkan, seorang yang mukmin dan beriman melakukan segala sesuatunya untuk mendapatkan keridhaan Allah dan berimplikasi pada penghargaan dan pujian sesama atas dirinya. ${ }^{14}$

\section{3) Motif loyalitas}

Islam mengajarkan bentuk loyalitas kepada keyakinan dan prinsip hidup, dan bukan loyalitas kepada sesuatu yang tidak ada hubungannya dalam diri individu, baik itu loyalitas kepada keluarga, suku, Negara maupun strata sosial. Loyalitas yang diakui keberadaannya oleh Islam adalah loyalitas keyakinan atas kebenaran Islam dan keyakinan bahwa manusia adalah satu umat yang sama.

Hal tersebut bukan berarti bahwa Islam tidak mengakui bentuk loyalitas lainnya. Islam mengakui loyalitas kekeluargaan yang ditunjukkan dengan disambungnya tali silaturrahmi, loyalitas kepada Negara yang ditunjukkan dengan sikap nasionalis, ataupun loyalitas kepada sesama manusia yang ditunjukkan dengan persaudaraan sesama manusia. ${ }^{15}$

\section{c. Motif Spiritual}

\section{1). Motif beragama.}

Kebutuhan untuk beragama adalah kebutuhan spiritual dan berlandaskan pada fitrah manusia. Allah berfirman:

“Maka hadapkanlah wajahmu dengan lurus kepada Agama (Allah); (tetapkanlah atas) fitrah Allah yang telah menciptakan manusia menurut fitrah itu. Tidak ada perubahan pada fitrah Allah. (Itulah) agama yang lurus; tetapi kebanyakan manusia tidak mengetahui". (ar-Ruum: 30)

Yang dimaksud fitrah disini adalah agama yang benar dan lurus, agama dimana seorang anak dilahirkan. Agama yang membuat seseorang cenderung untuk selalu melakukan kebaikan dan menjauhi semua keburukan. ${ }^{16}$ Seorang anak dilahirkan dalam ajaran Islam yang global. Ajaran Islamlah yang menjadikan keglobalan tersebut menjadi hal yang lebih spesifik, sebagaimana lingkungan yang menjadikan faktor genetik seseorang menjadi lebih spesifik. Agama bisa dikatakan sebagai faktor genetik spiritual dalam diri manusia. Perilaku ini tersembunyi dan baru akan tampak dalam suatu masyarakat yang selaras dengannya. Inilah perilaku spiritual yang baru akan tampak dengan benturan ajaran agama Islam dalam fenomena realitas yang terjadi dalam kehidupan.

Motif ini tampak dengan berbagai gambarannya seperti kecenderungan manusia untuk melakukan beragam ibadah seperti mencium hajar aswad, thawaf, sujud, dan banyak lainnya, terlepas dari bentuk peribadahan yang ada. Allah telah mengutus para Rasul-Nya agar manusia mampu memenuhi kebutuhan beragama dengan jalan yang lurus hingga ia tidak menyimpang dari batasan yang telah ditentukan. ${ }^{17}$ Motif beragama sesungguhnya adalah motif spiritual yang mandiri dan bahkan merupakan motif yang jelas dan tampak terlihat dalam kehidupan masyarakat.

Motivasi beragama merupakan dorongan psikis yang mempunyai landasan ilmiah dalam

${ }^{14}$ Ibid, Hlm. 686-687.

${ }^{15} \mathrm{Ibid}, \mathrm{Hlm} .688$.

${ }^{16} \mathrm{Ibid}, \mathrm{Hlm} .690$. 
Fatma Laili Khoirun Nida| Membangun Motivasi Beragama 11

watak kejadian manusia dimana mereka merasakan adanya dorongan untuk mencari dan memikirkan penciptanya, dan pencipta alam semesta dan dorongan untuk menyembahnya dan meminta pertolongan setiap kali ia ditimpa malapetaka. ${ }^{18}$ Motivasi beragama sangat berkaitan langsung dengan perjalanan rohani seseorang untuk mencari keridhoan Allah. ${ }^{19}$

Allah menciptakan manusia dengan kesempurnaan yang menyeluruh. Hal ini sebagai modal yang diberikan Allah bagi manusia untuk menjalankan tugasnya sebagai khalifah di muka bumi. Selain sebagai khalifaah, Allah menjadikan fitrah manusia sebagai makhluk yang beragama. Sifat dasar manusia sebagai makhluk yang beragama inilah yang oleh Danah Zohar dan Ian Marshall disebutkan bahwa di dalam otak manusia terdapat apa yang mereka sebut sebagai "titik Tuhan" atau "God Spot”. Dalam karyanya, Zohar dan Marsall mengangkat hasil penelitian yang dilakukan oleh pakar neorobiologi semacam Persinger dan Ramachandran yang menyebutkan bahwa terdapat bagian dalam otak yang disebut dengan lobus temporal yang berkaitan dengan pengalaman religious atau spiritual. Sebagian pakar berpendapat bahwa titik tuhan ini telah berevolusi di dalam otak untuk tujuan tertentu. ${ }^{20}$

Penegasan bahwa kebutuhan beragama terdapat dalam diri manusia pun telah dijelaskan oleh bapak psikologi Humanistik, Abraham Maslow. Maslow menjelaskan bahwa manusia memiliki kebutuhan yang berjenjang dari kebutuhan dasar hingga kebutuhan paling puncak. Pertama, kebutuhan dasar atau kebutuhan fisiologis seperti kebutuhan makan, minum, istirahat dan sebagainya, kedua adalah kebutuhan akan rasa aman yang mendorong manusia untuk bebas dari rasa takut sehingga termanifestasikan dalam bentuk pemenuhan kebutuhan untuk tempat tinggal yang permanen. Ketiga adalah kebutuhan akan kasih sayang, yang diantaranya dipenuhi dengan interaksi anta manusia, saling membagi perhatian, keintiman dan pergaulan hidup. Keempat adalah kebutuhan harga diri (self esteem) yang dimanifestasikan dalam bentuk aktualisasi diri anatara lain dengan berbuat sesuatu yang berguna. Pada tahap ini orang ingin agar buah pikirannya dihargai. Pengalaman puncak yang transenden digambarkan sebagai kondisi sehat super normal (normal super healthy) dan sehatt super-super (super-super healthy) yang oleh Maslow disebut peakers. Peakers memiliki penglaman puncak yang memberikan wawasan yang jelas tentang diri mereka dan dunia mereka. ${ }^{21}$

Dorongan beragama merupakan dorongan jiwa yang alami dalam karakter penciptaan manusia. Karena dalam kedalaman jiwanya manusia merasakan suatu dorongan yang mendorongnya berpikir dan mengetahui Penciptanya dan Pencipta alam semesta ini, memikirkan cara beribadah kepada-Nya, meminta pertolonganNya ketika berada dalam kesulitan atau tertimpa musibah, dan ia akan merasakan rasa aman dan ketenangan dalam perlindungan dan pemeliharaan-Nya. ${ }^{22}$

Dari pendapat tersebut maka dapat disimpulkan bahwa motivasi beragama merupakan kekuatan yang menggerakkan seseorang untuk merespon pranata ke-tuhanan sehingga orang tersebut mampu mengungkapkan dalam bentuk pemikiran dan perbuatan. Adapun aspek yang terdapatdalam motivasi beragama terdiri dari tiga hal, yakni dorongan untuk memeluk agama, kecenderungan untuk menjalankan ajaran agama dan adanya tujuan hidup yang sesuai dengan ajaran agama.

Ibid, Hlm. 690-691.

${ }^{18}$ Faizah, Psikologi dakwah, Jakarta, Kalam Mulia, 2003, hal 34.

${ }^{19}$ Ramayulis, Psikologi Agama, Jakarta, kalam Mulia, 2003, hal 44

${ }^{20}$ Danah Zohar dan Ian Marshall, SQ; Memanfaatkan Kecerdasan Spiritual dalam Berfikir Holistik Untuk Memaknai Kehidupan, terj, Bandung: Mizan Media Utama, 2001, hal 82 


\section{Kebermaknaan Hidup}

Setiap individu tentu memiliki kebutuhan yang cukup besar akan kebermaknaan hidupnya. Mengkaji tentang kebermaknaan hidup, maka tidak akan bisa melepaskan diri dari sumber-sumber kebermaknaan hidup itu sendiri. Menurut Victor E. Frankl, melalui Logoterapi nya menjelaskan bahwa makna hidup adalah hal-hal yang oleh seseorang dipandang penting, dirasakan berharga dan diyakini sebagai sesuatu yang benar serta dapat dijadikan tujuan hidupnya. Setiap individu normal senantiasa menginginkan dirinya menjadi orang yang berguna dan berharga bagi keluarganya, lingkungannya serta bagi dirinya sendiri.

Keinginan ini merupakan motivasi utama bagi setiap manusia. Hasrat inilah yang mendasari manusia dalam beraktifitas misalnya bekerja, berkarya, agar hidupnya dirasa berarti dan berharga. Hasrat ini yang menjadikan diri kita menjadi pribadi yang bermartabat, terhormat dan berharga (being somebody) dengan kegiatan yang mengarah pada tujuan hidup yang jelas dan bermakna. Terpenuhinya hasrat untuk hidup bermakna akan menimbulkan perasaan bahagia, dan sebaliknya kegagalan dalam pemenuhan untuk hidup bermakna akan berdampak pada kekecewaan hidup dan penghayatan diri hampa tak bermakna yang bila dibiarkan berlarut-larut akan berdampak pada gangguan penyesuaian diri, hambatan pengembangan pribadi dan harga diri. ${ }^{23}$

\section{Dorongan Hidup Bermakna}

Manusia dan keinginan untuk hidup bermakna merupakan satu kesatuan yang tidak dapat dipisahkan. Makna hidup adalah sesuatu yang oleh seseorang dirasakan penting, berharga dan diyakini sebagai sesuatu yang benar serta dapat menjadi tujuan hidupnya. Makna hidup

${ }^{21}$ Jalaluddin, hal 133-134

${ }^{22}$ Muhammad Utsman Najati, Psikologi Qurani; Dari Jiwa Hingga Ilmu Laduni, Marja, Bandung, 2010, Hlm. 37. dapat berupa cita-cita maupun sekedar keinginan untuk membuat seseorang dapat bertahan hidup. Kebermaknaan hidup akan dimiliki seseorang jika dia dapat mengetahui apa makna dan tujuan hidupnya.

Motivasi yang sangat kuat dalam diri manusia untuk memperoleh hidup yang bermakna berlaku pada seluruh manusia tanpa mengenal lapisan budaya maupun aspek-aspek kemanusiaan yang lain. Mutlaknya kebutuhan akan makna hidup ini ditunjukkan oleh beberapa penelitian tentang kebutuhan individu akan makna hidupnya. Hasil pengumpulan pendapat umum di Prancis, misalnya, menunjukkan $89 \%$ responden percaya bahwa manusia membutuhkan "sesuatu" demi hidupnya, sedangkan $61 \%$ di antaranya merasa bahwa ada sesuatu yang untuknya mereka rela mati. ${ }^{24}$ Bahkan dalam sebuah penelitian menyebutkan bahwa dua diantara sepuluh penyebab kematian tertinggi di Dunia Barat adalah alkoholisme dan bunuh diri yang disebabkan oleh krisis makna hidup yang menimpa mereka. ${ }^{25}$

Dari bukti empiris tersebut mampu menggambarkan bahwa eksistensi kebermaknaan hidup menjadi kebutuhan yang mutlak khususnya pada masyarakat yang telah mengalami kompleksitas permasalahan hidup yang berindikasi adanya stressor yang kerap berdampak pada ketidakstabilan emosi, melemahnya kepercayaan diri, hilangnya motivasi untuk berkarya, merosotnya nilai-nilai kehidupan dan dorongan untuk berperilaku amoral yang mengarah pada psikososial.

\section{Logoterapi}

Aliran Psikologi yang banyak memberi kajian tentang fenomena makna hidup (the meaning of

\footnotetext{
${ }^{23}$ Bastaman, hal 194

${ }^{24} \mathrm{Frankl}, 2003$, hal 110

${ }^{25}$ Zohar dan Marshall, 2008, hal 18
} 
Fatma Laili Khoirun Nida| Membangun Motivasi Beragama

life) dan pengembangan hidup bermakna adalah Logoterapi yang ditemukan oleh Viktor E. Frankl, seorang neuropsikiater berkebangsaan Austria. Menurut Frankl, ada beberapa hal yang menjadi landasan munculnya Logoterapi ini yakni;

a. Dalam setiap keadaan, termasuk dalam penderitaan sekalipun, kehidupan ini selalu mempunyai makna.

b. Kehendak untuk hidup bermakna merupakan motivasi semua manusia.

c. Dalam batas-batas tertentu, manusia memiliki kebebasan dan tanggung jawab pribadi untuk memilih dan menentukan makna dan tujuan hidupnya.

d. Hidup bermakna dapat diperoleh dengan merealisasikan nilai-nilai kreatif, nilai-nilai penghayatan serta dilai-nilai dalam bersikap. $^{26}$

Dari keempat dasar inilah Frankl mengembangkan Logoterapi, sebuah metode yang membantu individu dalam pencarian kebermaknaan hidup. Dalam perannya, Logoterapi berusaha memasuki dimensi spiritual dari eksistensi manusia dengan mengoptimalkan kesadarannya secara penuh akan sesuatu. Dalam usahanya mewujudkan kesadaran penuh pada individu, Logoterapi berusaha menjaga eksistensi spiritual sebagai potensi yang harus diisi. Logoterapi mencoba membuat individu sadar akan apa yang ia butuhkan di kedalaman eksistensinya. Untuk itu, Logoterapi memperhatikan manusia sebagai sebuah keberadaan yang perhatian utamanya adalah untuk mengisi makna dan aktualisasi nilai-nilai kehidupan.

Esensi yang dapat diadopsi dari Logoterapi ini adalah bentuk pijakan atau landasan yang digunakan Frankl dalam membantu individu untuk mencapai kebermaknaan hidup. Empat hal yang menjadi dasar dalam menganalisis dan mem-

${ }^{26}$ Bastaman, hal 193 batu proses individu dalam pencarian hidup yang bermakna, hendaklah efektif dalam aktualisasinya. Untuk itulah,maka banyak proses terapi kebermaknaan hidup berpijak dari dasar-dasar yang menjadi acuan bagi Frankl dalam mengembangkan metode Logoterapi dan terbukti efektif, dimana pada kenyataannnya, manusia memiliki motivasi untuk hidup bermakna. Di sini terdapat lima metode yang dapat digunakanuntuk menjajagi sumber makna hidup seseorang yakni

a. Pemahaman pribadi, metode ini pada dasarnya membantu memperluas dan mendalami beberapa aspek kepribadian dan corak kehidupan seseorang.

b. Bertindak positif, metode bertindak positif didasari oleh pemikiran bahwa dengan cara membiasakan diri melakukan tindakan-tindakan positif, akan memberi dampak positif terhadap perkembangan pribadi dan kehidupan social seseorang.

c. Pengakraban hubungan, metode pengakraban hubungan menganjurkan agar seseorang membina hubungan yang akrab dengan orang tertentu (misalnya: anggota keluarga, teman, dan rekan sekerja) sebab dalam hubungan pribadi yang akrab dengan seseorang benar-benar merasa diperlukan dan memerlukan orang lain, dicintai dan mencintai orang lain tanpa mementingkan diri sendiri.

d. Pendalaman tri nilai yang dimaksud dengan pendalaman tri nilai adalah usaha-usaha untuk memahami benar-benar nilai kreatif, nilai penghayatan, dan nilai bersikap.

e. Menjalankan ibadah dengan melaksanakan apa yang diperintahkan Tuhan dan mencegah diri dari hal-hal yang dilarang-Nya menurut ketentuan agama. Ibadah yang dilakukan secara khidmat sering menimbulkan perasaan tentram, mantap, dan tabah seakan-akan mendapat bimbingan dalam melakukan tindakan-tindakan penting. 
116 畜

NUANSA Vol. XII, No. 1, Juni 2019

Eksistensi makna bersifat unik, dan personal. Setiap orang yang lahir kedunia pasti mewakili sesuatu yang baru. Tugas setiap orang adalah untuk memahami bahwa tidak ada seorangpun yang serupa dengan dirinya, dan untukitulah dia diperlukan keberadaannya sebagai sesuatu yang baru dan dan harus memenuhi suatu panggilan di dunia. ${ }^{27}$

\section{Sumber-Sumber Kebermaknaan Hidup}

Frankl mengatakan bahwa ada tiga faktor yang berpengaruh pada diri manusia sehingga ia dengan mudah dapat mencapai tingkat kehidupan yang bermakna;

a) Creative values (nilai-nilai kreatif): bekerja dan berkarya serta melaksanakan tugas dengan keterlibatan dan tanggung jawab pada pekerjaan. Dalam realisasinya, manusia menjalani dinamika hidupnya dengan bekerja adalah untuk menjadi sarana baginya dalam menemukan dan mengembangkan makna hidup.

b) Experiental values (nilai-nilai penghayatan): kemampuan untuk meyakini dan menghayati kebenaran, kebajikan, keindahan, keadilan, keimanan, dan nilai-nilai lain yang dianggap berharga.

c) Attitudinal values (nilai-nilai bersikap), menerima dengan tabah dan mengambil sikap yang tepat terhadap penderitaan yang tak dapat dihindari lagi setelah berbagai upaya dilakukan secara optimal tetapi tak berhasil mengatasinya ${ }^{28}$ Sebuah penelitian menunjukkan bahwa 85\% kesuksesan hidup seseorang ditentukan oleh sikapnya, sedangkan 15\% ditentukan oleh kemampuannya. Bahkan menurut William James, manusia dapat mengubah hidupnya dengan cara mengubah sikapnya. Sikap merupakan cara pandang secara mental tentang apa yang terjadi dalam diri kita, orang lain, keadaan dan kehidupan secara umum. Maka orang dengan sikap positif akan melahirkan harapan yang baik dalam hidupnya. ${ }^{29}$

Ketiga hal tersebut diatas merupakan modal yang mutlak harus dimiliki oleh tiap individu agar pencapaian kebermaknaan hidup terpenuhi. Kemampuan manusia untuk mengupayakan penanaman nilai-nilai diatas sangat berdampak pada bagaimana ia menjalani dinamika kehidupannya dalam kondisi apapun. Individu akan memiliki kekuatan yang muncul pada diri mereka dalam kondisi menderita sekalipun disebabkan adanya kemampuan individu untuk meghayati segala keadaan yang menimpanya dengan tetap berfikir positif serta optimis dalam menjalani hidup.

Dengan mengembangkan konsep yang dimiliki Frankl, Crumbaugh dan Maholick menjelaskan bahwa karakteristik individu dengan pencapaian makna hidup dapat dilihat dari ciricirinya yakni : (a) memiliki tujuan yang jelas, yaitu segala sesuatu yang dilakukan memiliki kejelasan akan tujuan hidup, (b) kepuasan hidup, dimana sejauhmana seseorang dapat menikmati dan merasa puas menjalani aktivitas, (c) kebebasan berkehendak, yakni mampu mengendalikan kebebasan hidup yang dilakukan secara bertanggungjawab,(d) Kontrol diri, dimana dalam keadaan apapun manusia masih bisa melestarikan kebebasan spiritual dan kebebasan berfikir, (e) sikap terhadap kematian, yaitu bagaimana seseorang berpandangan dan kesiapannya menghadapi kematian, (f) mampu memiliki alasan untuk tetap eksis. Hal ini sebagaimana yang dikatakan oleh Nietzsche "he who has a way to live fo can bear with almost any how".30

Urgensiuntukhidup bermakna menjadi salah satu motivator bagi individu dalam berperilaku. Seseorang yang hidupnya hampa cenderung

27Zainal Abidin, Analisis Eksistensial Untuk Psikologi dan Psikiatri, Bandung, Refika Aditama,2002, hal 172

76

${ }^{28}$ Hal Urban, Bangkit Dari Kegagalan, terj, Yogyakarta: Think, 2003, hal 
Fatma Laili Khoirun Nida| Membangun Motivasi Beragama 11

mudah putus asa, dan sebaliknya seseorang yang hidupnya bermakna maka mereka akan cenderung optimis dan pantang menyerah ${ }^{31}$ Untuk itulah maka banyak pengalaman yang bersifat personal sering merubah sifat dan perilaku individu ke arah lebih baik sebagai upayanya untuk mencapai hidup yang bermakna.

\section{Motivasi Beragama Para Perempuan Peker- ja Seks Komersial di Lokalisasi Lorong In- dah Kabupaten Pati.}

Eksistensi motivasi beragama tetap menjadi bagian dari kehidupan spiritual PSK di Kompleks Lokalisasi Lorong Indah Kabupaten Pati. Beberapa fenomena kehidupan beragama dijumpai peneliti dari beberapa kegiatan observasi maupun dalam wawancara serta respon yang muncul dari angket yang disebar peneliti di lokasi. Kedudukan motif beragama dalam hal ini dapat dipandang dari beberapa aspek, diantaranya:

\section{a) Motif beragama sebagai motif spiritual.}

Dalam karyanya, Zohar dan Marsall mengangkat hasil penelitian yang dilakukan oleh pakar neorobiologi semacam Persinger dan Ramachandran yang menyebutkan bahwa terdapat bagian dalam otak yang disebut dengan lobus temporal yang berkaitan dengan pengalaman religious atau spiritual. Sebagian pakar berpendapat bahwa titik tuhan ini telah berevolusi di dalam otak untuk tujuan tertentu. ${ }^{32}$ Dalam realitanya, kondisi yang jauh dari idealnya norma soaial maupun norma agama, para pekerja seks komersial masih menunjukkan kehidupan beragama dalam beberapa sisi kehidupan yang mereka miliki. Keyakinan yang masih melekat dalam diri mereka akan keberadaan Tuhan, hari akhir takdir, surga, neraka, dosa, pahala dan beberapa aspek yang masuk dalam ranah relgiusitas masih sedikit banyak melekat dalam keyaki-

${ }^{30} \mathrm{Frankl}, 2004$, hal 85

${ }^{31}$ Ahmad Mubarok, Psikologi Dakwah, Membangun Cara Berfikir dan Merasa, Malang: Madani, 2014, hal 87 nan mereka.

\section{b) Motif beragama sebagai motif Kognitif}

Motif kognitif ini tidak berkaitan dengan dasar-dasar biologis dalam diri manusia. Ia adalah kebutuhan yang dipelajari manusia dari lingkungan dan sosial masyarakatnya. Tujuan dari motif kognitif adalah untuk menjaga diri dan mengembangkan kemampuannya. Dengan memenuhi dan memuaskannya, maka terealisasilah keseimbangan kejiwaan. Berlawan arah dengan keseimbangan fisik dan metabolisme tubuh yang terealisasi bila manusia mampu memnuhi kebutuhan atau motif naluriah instingtifnya. ${ }^{33}$ Contoh-contoh motif kognitif, yaitu:

\section{1) Motif keamanan.}

Rasa aman bagi seorang muslim tidak hanya dibutuhkan dalam kehidupan dunia saja, namun ia pun membutuhkannya kelak pada hari kiamat dari siksa Allah. Dengan persepsi inilah perilaku seorang muslim diarahkan untuk selalu beriman kepada Allah dan hari kiamat, dan pemenuhannya diarahkan pada penegakan nilainilai yang ada pada ajaran agamanya. ${ }^{34}$

Demikian juga dalam kehidupan PSK di Lokalisasi ini. Dalam kondisi penuh stressor, kebutuhan untuk mendekatkan diri pada Allah adakalanya tetap muncul ketika mereka merasa dalam kondisi penuh keputus-asaan Keyakinan bahwa Tuhan maha Pengampun membuat mereka masih menyisakan waktu untuk berdoa, sholat, puasa sunna dalam kondisi-kondisi tertentu. Dari kegiatan itu kemudian menjadi kekuatan bagi mereka untuk kembali bangkit dari kondisi yang depresif dan menjadi spirit bagi mereka untuk kembali optimis menatap masa depan.

\footnotetext{
${ }^{12}$ Danah Zohar dan Ian Marshall, SQ; Memanfaatkan Kecerdasan Spiritual dalam Berfikir Holistik Untuk Memaknai Kehidupan, terj, Bandung: Mizan Media Utama, 2001, hal 82

${ }^{13} \mathrm{Ibid}, \mathrm{Hlm} .680$

${ }^{14} \mathrm{Ibid}, \mathrm{Hlm} .683$
} 


\section{2) Motif untuk mengetahui sesuatu.}

Dalam aktualisasi pemenuhan motif kognitif ini, para PSK ternyata masih mampu untuk meluangkan sedikit waktu mereka untuk menggali pengetahuan seputar kehidupan keberagamaan mereka. Keberadaan kegiatan pengajian yang rutin mereka hadiri tiap dua minggu sekali, merupakan sarana bagi mereka untuk setidaknya menimba informasi seputar Sang Pencipta, kehidupan rosul maupun untuk mengenal nilainilai syariat Islam yang terkadang cukup mereka butuhkan. Tidak hanya itu, dari angket yang peneliti sebar, sebagian responden juga kerap mengkonsumsi pengetahuan agama mereka melalui radio, buku-buku bacaan keagamaan maupun internet.

Dari fenomena lapangan menjadi gambaran konkrit bahwa motivasi beragama merupakan dorongan psikis yang mempunyai landasan ilmiah dalam watak kejadian manusia dimana mereka merasakan adanya dorongan untuk mencari dan memikirkan penciptanya, dan pencipta alam semesta dan dorongan untuk menyembahnya dan meminta pertolongan setiap kali ia ditimpa malapetaka. ${ }^{35}$

Banyak hal yang menjadi gambaran mengapa potensi mereka yang pada dasarnya sebagai makhluk yang cenderung pada fitrah yang lurus ternayata harus memilih kehidupan yang jauh dari norma agama dan norma apaun di masyarakat, maka menyimpan bayak jawaban yang menjadi factor pemicu kehidupan yang mereka pilih tersebut. Diantaranya adalah factor ekonomi, factor lingkungan, factor frustasi bahkan mungkin sekedar dari pilihan gaya hidup. Sekalipun mayoritas dari mereka menjadikan kondisi ekonomi sebagai salah satu alasan mengapa mereka melakukan pekerjaan haram tersebut, namun tidak sedikit pula yang ternyata dipicu oleh lingkungan pertemanan yang mempengaruhi keputusan mereka memilih jalan hidup tersebut. Namun, pilhan ini tidak serta merta muncul melainkan dipicu oleh peristiwaperistiwa traumatis dalam kehidupanmereka sebelumnya misalnya karena perceraian, pengkhianatan dalam hubungan asmara dengan pasangan sebelumnya, kehamilan diluar nikah yang pernah terjadi sebelumnya, pergaulan yang salah dan yang paling banyak adlah frustasi sehingga menjadikan dunia prostitusi sebagai pelarian.

Berlarut-larutnya mereka dalam kondisi yang rumit dan menempatkan mereka pada posisi yang marginal bukan menjadi alasan bagi mereka untuk meniadakan keberlangsungan kehidupan spiritualnya. Kekuatan dorongan kehidupan beragama tetap menjadi milik mereka meskipun dengan kondisi yang sangat ala kadarnya. Pada dasarnya, faktor yang dapat membantu untuk membangunkan dorongan beragama adalah situasi sulit atau bahaya yang mengancam hidupnya. Demikianlah kondisi manusia dimana dan kapanpun, sejak dimulai penciptaanya, jika merasakan suasana ynag mengancam dan menakutkan, ia akan meminta perlindungan kepada Zat yang lebih kuat. Hal ini menunjukkan bahwa fitrah untuk beragama sudah ada dalam karakter manusia. ${ }^{36}$

Fenomena eksistensi dorongan beragama merupakan konstruk realitas social yang saling berdialeektis antara dirinya dan kenyataan. Implikasinya perasaan ketergantungan yang besar dari sosok pelacur pada realitas transcendental sebagai tempat menggantungkan harapan semakin tinggi. Dari sinilah maka dapat dikatakan bahwa kesadaran pelacur dalam beragama merupakakan kesadaran yang bersifat fakta hakiki kesadaran kemanusiaan yang terkonstruk dari realitas social. Sifat dasar instingtif manusia yang sangat lemah membutuhkan realitas social yang akhirnya bermuara pada realitas transcendental (Tuhan). ${ }^{37}$

${ }^{35}$ Faizah, Psikologi dakwah, Jakarta, Kalam Mulia, 2003, hal 34. 
Pada akhirnya motivasi beragama pada diri perempuan pekerja seks komersial mendudukkan pada kondisi yang tidak berbeda dengan motivasi beragama yang dimiliki oleh manusia pada umumnya. Yang menjadi ciri pembeda dari keberagamaan mereka adalah stigma masyarakat yang memandang agama mereka sebagai wajah yang marginal, yang dipandang masyarakat penuh aprioristic dan bahkan tidak diakui oleh kalangan masyarakat umumnya.

\section{Kebermaknaan Hidup dan Upaya Pengem- bangannya Bagi Perempuan Pekerja Seks Komersial.}

Sebagaimana pendapat Frankl yang mendefinisikan bahwa makna hidup adalah hal-hal yang oleh seseorang dipandang penting, dirasakan berharga dan diyakini sebagai sesuatu yang benar serta dapat dijadikan tujuan hidupnya. Setiap individu normal senantiasa menginginkan dirinya menjadi orang yang berguna dan berharga bagi keluarganya, lingkungannya serta bagi dirinya sendiri. Bila berpijak dari dimensi kebermaknaan hidup yang dipaparkan oleh Crumbaugh dan Maholick, maka kualitas pencapaian makna hidup dapat dilihat indicator di bawah ini :

(a) memiliki tujuan yang jelas, yaitu segala sesuatu yang dilakukan memiliki kejelasan akan tujuan hidup,dimana dari data dalam angket menjelaskan bahwa $90 \%$ responden memiliki tujuan hidup yang cukup jelas dalam kehidupan mereka yakni ingin membahagiakan keluarga. Kekuatan dari tujuan hidup yang mereka miliki inilah yang menjadi daya dukung bagi mereka untuk menciptakan sikap optimis dalam perjalanan

${ }^{36} \mathrm{Ibid}, \mathrm{Hlm} .39-40$

${ }^{37}$ Erfan dan Umiarso, 2016, Konsep Tuhan Perspektif Pelacur; Kajian Kritis Analitik dalam frame Dramaturgis Profanistik, Yogyakarta, Pustaka pelajar, hal 260-261 hidup yang mereka lalui, sementara sebagaimana telah dikemukakan diatas bahwa sikap optimis ternayata mampu menciptakan kekuatan bagi seseorang untuk mencapai hidup secara bermakna.

(b) Kepuasan hidup, adalah sejauhmana seseorang dapat menikmati dan merasa puas menjalani aktivitas. Pada dimensi ini, 58 persen menjawab cukup puas, dan 20 persen sangat puas dan selebihnya sebanyak 22 persen mereka merasa tidak puas akan keadaan hidup yang mereka rasakan. Capaian kepuasan hidup yang tidak maksimal ini tentunya disebabkan oleh keadaan hidup yang tidak sebagaimana mereka kehendaki. Profesi sebagai perempuan pekerja seks komersial serta segenap lingkungan baik fisik dan psikososial yang mengelilingi mereka memaksa mereka untuk mau tidak mau harus menerima sebagai satu-satunya pilihan lahan yang dapat mensupport keberlangsungan hidup mereka. Bila ditinjau dari dimensi ini, maka makna hidup dapat dikatakan tidak maksimal dapat terpenuhi karena tidak adanya konsistesni antara harapan dan kenyataan yang mereka rasakan.

(c) Kebebasan berkehendak, yakni mampu mengendalikan kebebasan hidup yang dilakukan secara bertanggungjawab. Meskipun kedudukan profesi mereka dipandang amoral, namun kebanyakan dari mereka merasakan tetap memiliki makna dalam hidupnya karena apapun yang terjadi dalam kehidupan mereka merupakan hasil keputusan sebgian besar dari responden termasuk pilihan untuk menjadi pekerja seks komersial. Sebagian besar dari mereka (88 persen) merasakan bahwa semua keputusan menyangkut kehidupan mereka adalah hasil dari keputusan mereka secara independent. Kebebasan inilah yang memiliki kekuatan untuk menciptakan kehidu- 
pan mereka menjadi lebih bermakna.

(d) Kontrol diri, dimana dalam keadaan apapun manusia masih bisa melestarikan kebebasan spiritual dan kebebasan berfikir. Meskipun dalam kondisi yang tidak menguntungkan, kemampuan kontrol diri mereka cukup baik. Dinamika kehidupan di lingkungan prostitusi sangat dekat dengan kekerasan, persaingan, penuh konflik dan depresif. Mayoritas dari responden atau lebih tepatnya 84 persen dari jumlah sample memilih tetap bersabar dan berdoa saat mereka dihadapkan pada suatu masalah dalam hidup. Kemampuan control diri yang baik menciptakan kekuatan tersendiri bagi mereka untuk membangun makna dalam hidup mereka. Dalam posisi apapun mereka yakin bahwa dengan kesabaran dan membawa mereka lepas dalam kehidupan tersebut dan pada akhirnya akan membawa kehidupan mereka untuk lebih baik di masa mendatang.

(e) sikap terhadap kematian, yaitu bagaimana seseorang berpandangan dan kesiapannya menghadapi kematian. Bila ditinjau dari dimensi ini, mayoritas mereka merasa takut bila mengingat kematian yakni sebanyak 64 persen responden. Ketakutan terhadap kematian menjadi salah satu indicator yang melemahkan kualitas kebermaknaan hidup mereka. Sikap takut terhadap kematian mereka rasakan lebih disebabkan ketidaksiapan mereka untuk menjalani proses tersebut. Namun sebaliknya, pada beberapa responden, merasakan sikap yang netral atau biasa-biasa saja terhadap datangnya kematian. Bagi mereka yang meyakini keberadaan Tuhan yang menciptakan kehidupan sudah barang tentu akan berakhir dengan kematian. Bila ditinjau lebih dalam lagi, ternyata respon ini berkorelasi dengan motivasi keberagamaan mereka. Keyakinan akan Tuhan, dan segala pengetahuan tentang kasih sayang Tuhan dalam perspektif mereka kerap menimbulkan harapan akan pengampunan bagi mereka. Pada akhirnya menumbuhkan sikap positif terhadap eksistensi kematian yang pasti akan menjadi bagian dari kehidupan mereka.

(f) mampu memiliki alasan untuk tetap eksis. Sebagaimana telah disebutkan di atas bahwa mayoritas mereka menjadikan keluarga sebagai salah satu alasan terkuat untuk bertahan dalam kehidupan yang serba sulit. Motivasi untuk membahagiakan keluarga, baik bagi mereka yang sudah menikah maupun yang belum ternyata memiliki posisi yang utama bagi mereka untuk tetap menjalani semua kehidupan sekaligus profesi mereka dengan segala konsekwensi yang mereka terima dari masyarakat. Kebahagiaan bagi mereka terletak pada kepuasan untuk dapat memberi kehidupan yang lebih sejahtera bagi keluarga dengan kehidupan perekonomian yang lebih baik, pendidikan anak yang lebih tinggi bahkan tabungan untuk masa depan anak mereka. Kondisi ini menjadi gambaran nyata bahwa mereka merasakan kebermaknaan akan hidup mereka dengan kekuatan eksistensi mereka dalam mensupport perekonomian dalam keluarga masing-masing.

\section{Intervensi Makna Hidup dalam Meningkat- kan Motivasi Beragama Perempuan Peker- ja Seks Komersial Di Lokalisasi Lorong In- dah Pati}

Frankl menjelaskan bahwa terdapat lima metode yang dapat digunakan untuk menjajagi sumber makna hidup seseorang yakni:

a. Pemahaman pribadi, metode ini pada dasarnya membantu memperluas dan mendalami beberapa aspek kepribadian dan corak kehidupan seseorang. 
Fatma Laili Khoirun Nida| Membangun Motivasi Beragama 12

b. Bertindak positif, metode bertindak positif didasari oleh pemikiran bahwa dengan cara membiasakan diri melakukan tindakan-tindakan positif, akan memberi dampak positif terhadap perkembangan pribadi dan kehidupan social seseorang.

c. Pengakraban hubungan, metode pengakraban hubungan menganjurkan agar seseorang membina hubungan yang akrab dengan orang tertentu (misalnya: anggota keluarga, teman, dan rekan sekerja) sebab dalam hubungan pribadi yang akrab dengan seseorang benar-benar merasa diperlukan dan memerlukan orang lain, dicintai dan mencintai orang lain tanpa mementingkan diri sendiri.

d. Pendalaman tri nilai yang dimaksud dengan pendalaman tri nilai adalah usaha-usaha untuk memahami benar-benar nilai kreatif, nilai penghayatan, dan nilai bersikap.

e. Menjalankan ibadah dengan melaksanakan apa yang diperintahkan Tuhan dan mencegah diri dari hal-hal yang dilarang-Nya menurut ketentuan agama. Ibadah yang dilakukan secara khidmat sering menimbulkan perasaan tentram, mantap, dan tabah seakan-akan mendapat bimbingan dalam melakukan tindakan-tindakan penting.

Menjalankan ibadah sebagai dimensi yang ke lima yang menjadi salah satu variable yang diteliti dalam riset ini dimana dimensi ini oleh peneliti diidentifikasikan sebagai motivasi beragama. Dan sebagaimana dalam analisis di atas sebelumnya telah dijelaskan bahwa motivasi beragama subjek cukup tinggi dalam beebrapa aspek. Untuk itu maka kontribusi variable ini dapat mensupport proses pencapaian makna hidup sekalipun mereka berada dalam kondisi yang jauh dari linngkungan yang normative religious. Beberapa responden yang diwawancarai penelitipun menjelaskan bahwa mereka sesekali tetap menjalankan ibadah puasa sunnah misalnya sebagai upaya untuk mewujudkan harapan akan keberhasilan anak mereka saat menjalani ujian nasional. Menjalankan sholat tetap sesekali mereka upayakan khususnya saat mereka merasa dalam kondisi tertekan dengan permasalahan hidup yang mereka hadapi. Motivasi beragama juga mereka tunjukkan dalam antusiasme mereka untuk menghadiri pengajian rutin dwi mingguan sebagai upaya untuk menambah pengetahuan keagamaan mereka.

Dalam data yang diperoleh peneliti, ternyata subjek yang memiliki motivasi beragama cukup tinggi menunjukkan keberhasilan untuk mencapai elemen-elemen kebermaknaan hidup. Mereka menunjukkan sikap yang positif dalam memandang kehidupan mereka sehinggga mereka memiliki tujuan hidup yang jelas, kepuasan hidup yang cukup tinggi, control diri yang baik, merasa memiliki kebebasan berkehendak dan sikap yang positif terhadap kematian. Capaian ini merupakan wujud nyata bahwa motivasi beragama inilah yang mampu memposisikan mereka untuk mampu memiliki sikap hidup yang positif tersebut.

Motivasi beragama merupakan motivasi dasar dari sekian banyak bentuk motivasi yang dianugerahkan Tuhan pada setiap manusia sebaga bentuk fitrah mereka. Bagi penulis fitrah beragama yang menempel pada setiap umat manusia menjadi naluri dasar dari eksistensi kemanusiaannya bahwa manusia adalah sosok yang bergantung pada dzat yang dirasa sebagai sumber kekuatan terlebih dalam posisi lemah mereka sebagai makhluk. Peneliti mencoba menguatkan analisis ini dengan berpijak pada pendapat Peter el Berger yang menjelaskan bahwa titik tolak eksistensi social pelacur sendiri adalah realitas social yang melingkarinya (kenyataan hidup sehari-hari).

Realitas social ini merepresentasikan diri sebagai kenyataan yang bisa ditafsirkan oleh 
manusia mempunyai makna subjektif sebagai satu dunia yang koheren. Maka oleh Erfan dan Umiarso (2016) dimaknai fenomena tersebut sebagai embrio kesadaran pelacur yang lahir dari lekuk kehidupan dan dosa yang dinikmati untuk memberikan manfaat pada jiwa yang nantinya lebih mendewasakan mereka dan arif dalam memyikapi dinamika kehidupan sebagai ralitas social. Ia menjelaskan bahwa dari kerangka kehidupan beragama pelacur menjelaskan bahwa kesadaran beragama seorang pelacur merupakan kesadaran hakiki kemanusiaan yangterkonstruk dari realitas social. Sifat instingtif manusia yang lemah membutuhkan realitas social yang pada akhirnya bermuara pada realitas yang bersifat transcendental (Tuhan), sehingga pada konteks ini beragama bagi pelacur merupakan fenomena yang bersifat dialektis

Adanya kebebasan berkehendak yang mereka rasakan menjadi celah bagi mereka untuk masih bisa memilih solusi-solusi apa yang harus mereka tempuh saat mereka dalam kondisi terpuruk, dan bagi mereka yang sedang dalam kondisi tersebut, beribadah adalah satu-satunya jalan terakhir untuk mencari titik terang penyelesaian masalah mereka minimal ketengan yang mereka butuhkan. Responden dengan kondisi tersebut ternyata memiliki capaian makna hidup yang cukup tinggi, yang lahir dalam bentuk optimism, kepuasan hidup, pemahaman diri yang baik. Pemahaman diri tersebut muncul dalam bentuk kesadaran mereka bahwa mereka bukan dalam kondisi yang ideal sehinnga cepat ataupun lambat mereka harus melepaskan profesi tersebut untuk menjadi individu yang lebih baik setidaknya memiliki kehidupan yang sesuai dengan norma agama dan norma social yang mereka yakini. Responden mengetahui dan menyadari bahwa setiap kehidupan berakhir dengan kematian, namun kesadaran ini tidak selalu berakhir dengan sikap negative terhadap kematian seperti takut. Sebaliknya, keyakinan bahwa kema- tian akan menjadi bagian akhir dari kehidupan mereka diterjemahkan sebagai motivasi bagi mereka untuk bergegas mencari kehidupan yang lebih baik, memperbaiki diri dan alas an bagi mereka untuk mengakhiri profesi mereka. Dan dalam perjalanan menuju harapan tersebut, mereka tetap berusaha untuk menempuh kebaikan-kebaikan yang mereka fahami sebagai penyeimbang dari keburukan hidup (kemaksiatan) yang sedang mereka jalani. Upaya tersebut merupakan bentuk ibadah yang mereka yakini dengan penuh harap akan mendatangkan keridhoan Allah meskipun mereka merasa dalam gelimang dosa seperti bersedekah, berbuat baik dengan sesama teman, menolong orang yang membutuhkan, berpuasa romadhon, menghadiri pengajian dan berbuat baik pada orang tua. Dalam pergulatan mereka untuk terus menguatkan dimensi-dimensi peribadatan itulah mereka merasakan lebih bahagia, lebih tenang, dan cukup puas dengan apa yang telah mereka upayakan dalam kebaikan tersebut karena mereka yakin bahwa Tuhan selalu mengampuni dosa mereka, mengabulkan doa mereka, Maha Mengetahui, dan prasangka-prasangka penuh optimis terhadap Sang Kholiq. Inilah fenomena menarik yang dijumpai oleh peneliti sebagai titik temu kebermaknaan hidup dengan motivasi beragama yang dimunculkan dalam bentuk saling menguatkan anatra satu dengan yang lainnnya. Penguatan dari kedua variable tersebut mendatangkan kepuasan dari sisi psikis mereka yang menjadii indicator bahwa mereka mampu mewujudkan hidup lebih bermakna.

\section{Simpulan}

Penelitian ini memberi jawaban bagaimana fenomena pencapaian makna hidup dan motivasi beragama bagi kelompok masyarakat yang berada dalam kehidupan yang dipandang jauh dari nilai-nilai agama seperti pada kelompok masyarakat yang berprofesi sebagai pekerja seks 
Fatma Laili Khoirun Nida| Membangun Motivasi Beragama 12

komersial. Sebagai sebuah fitrah, motivasi beragama tetap menjadi bagian dari kehidupan semua manusia termasuk para perempuan pekerja seks komersial di Lokalisasi Lorong Indah Pati.

Motivasi beragama sangat dekat dengan dinamika pencapaian makna hidup mereka. Proses pencapaian kebermaknaan hidup berpijak pada indikator kebebasan berkehendak, dimana dalam realisasinya, aspek ini berkontribusi menjadi celah bagi mereka untuk masih bisa memilih solusi-solusi apa yang harus mereka tempuh saat mereka dalam kondisi terpuruk, dan bagi mereka yang sedang dalam kondisi tersebut, beribadah adalah satu-satunya jalan terakhir untuk mencari titik terang penyelesaian masalah mereka, atau setidaknya untuk memperoleh ketenangan yang mereka butuhkan.

Responden dengan kesadaran akan kehidupan berketuhanan memiliki capaian makna hidup yang cukup tinggi, yang lahir dalam bentuk optimism, kepuasan hidup, pemahaman diri yang baik. Pemahaman diri tersebut muncul dalam bentuk kesadaran mereka bahwa mereka bukan dalam kondisi yang ideal sehingga cepat ataupun lambat mereka harus melepaskan profesi tersebut untuk menjadi individu yang lebih baik setidaknya memiliki kehidupan yang sesuai dengan norma agama dan norma social yang mereka yakini. Responden mengetahui dan menyadari bahwa setiap kehidupan berakhir dengan kematian, namun kesadaran ini tidak selalu berakhir dengan sikap negative terhadap kematian seperti takut. Sebaliknya, keyakinan bahwa kematian akan menjadi bagian akhir dari kehidupan mereka diterjemahkan sebagai motivasi bagi mereka untuk bergegas mencari kehidupan yang lebih baik, memperbaiki diri dan alas an bagi mereka untuk mengakhiri profesi mereka. Dan dalam perjalanan menuju harapan tersebut, mereka tetap berusaha untuk menempuh kebaikan-kebaikan yang mereka fahami sebagai penyeimbang dari keburukan hidup (kemaksia- tan) yang sedang mereka jalani. Dalam pergulatan mereka untuk terus menguatkan dimensi-dimensi peribadatan dan mereka merasakan lebih bahagia, lebih tenang, dan cukup puas dengan apa yang telah mereka upayakan dalam kebaikan tersebut karena mereka yakin bahwa Tuhan selalu mengampuni dosa mereka, mengabulkan doa mereka, dan prasangka-prasangka penuh optimis terhadap Sang Kholiq. Inilah fenomena menarik yang dijumpai oleh peneliti sebagai titik temu kebermaknaan hidup dengan motivasi beragama yang dimunculkan dalam bentuk saling menguatkan antara satu dengan yang lainnnya. Penguatan dari kedua variable tersebut mendatangkan kepuasan dari sisi psikis mereka yang menjadi indikator bahwa mereka mampu mewujudkan hidup lebih bermakna.

\section{Daftar Pustaka}

Ahmad Mubarok, Psikologi Dakwah, Membangun Cara Berfikir dan Merasa, Malang: Madani, 2014.

Baharuddin, Paradigma Psikologi Islam; Studi tentang Elemen Psikologi dari Al qur'an, Yogyakarta, Pustaka Pelajar.

Bimo Walgito, Psikologi Umum, Yogyakarta, Andi, 2003.

Danah Zohar dan Ian Marshall, SQ; Memanfaatkan Kecerdasan Spiritual dalam Berfikir Holistik Untuk Memaknai Kehidupan, terj, Bandung: Mizan Media Utama, 2001.

Erfan dan Umiarso, 2016, Konsep Tuhan Perspektif Pelacur; Kajian Kritis Analitik dalam Frame Dramaturgis Profanistik, Yogyakarta, Pustaka Pelajar.

Faizah, Psikologi dakwah, Jakarta, Kalam Mulia, 2003.

Hal Urban, Bangkit Dari Kegagalan, terj, Yogyakarta: Think, 2003.

Hanna Djumhana Bastaman, Integrasi Psikologi Dengan Islam,; Menuju Psikologi Islam, 1995, Yogyakarta, pustaka pelajar, 1995. 
124

NUANSA Vol. XII, No. 1, Juni 2019

Muhammad Izuddin Taufiq, Panduan Lengkap dan Praktis Psikologi Islam, Gema Insani, Jakarta, 2006.

Muhammad Utsman Najati, Psikologi Qurani; Dari Jiwa Hingga Ilmu Laduni, Marja, Bandung, 2010.

Nur Syam, Agama Pelacur : dramaturgi Transendental, Yogyakarta: LKiS, 2010.
Ramayulis, Psikologi Agama, Jakarta, Kalam Mulia, 2003.

Victor E. Frankl, Logoterapi ; Terapi Psikologi Melalui Pemaknaan Eksistensi, terj, Yogyakarta: Kreasi Wacana, 2003.

Zainal Abidin, Analisis Eksistensial Untuk Psikologi dan Psikiatri, Bandung, Refika Aditama,2002. 